of that country; Academician N. S. Schatsky, of the Academy of Sciences, Moscow, for his work on tectonics, stratigraphy and economic geology; Dr. F. Prantl, vice-president of the National Museum, Prague, in recognition of his distinguished researches in palæography, stratigraphy and palæontology; Prof. Norman D. Newell, of the American Museum of Natural History, New York, for his contributions to invertebrate palæontology and his work on reef deposition.

\section{British Broadcasting Corporation Science Unit}

A ScIEnce UnIT has been established by the British Broadcasting Corporation with the object of providing a more extensive coverage of science in sound programmes. The senior member of the Unit is Dr. Archie Clow, who joined the B.B.C. in 1945 and has produced many science series and individual talks, notably the two weekly series "Science Survey" and "Who Knows?", in which leading experts deal with all kinds of scientific developments in a nontechnical way. The Unit is also responsible for "Science Review" and Third Programme science talks and discussions. Recently, Mr. David Edge joined Dr. Clow in the Talks Department. Both received their earlier education at Aberdeen, the former at Aberdeen Grammar School and the latter at Robert Gordon's College. Mr. Edge did research work in radio astronomy for three years after taking his degree in physics at Cambridge in 1955.

A third member of the Corporation staff who is contributing to the expansion of science broadcasts is Mr. C. L. Boltz, who is now attached to the News Division as science correspondent (Nature, 183, $1231 ; 1959)$. He formerly worked for seven years in a similar capacity in the B.B.C.'s European Service. Succeeding Mr. Boltz in the European Service is Mr. Bryan Silcock, who was born in Liverpool in 1933 and has since 1957 been an assistant editor of Nature. He went to Dartington Hall School in Devon, and after National Service in the West Yorkshire Regiment and the Royal Artillery, to Jesus College, Cambridge, graduating with honours in natural science.

\section{British Commonwealth Education Liaison Com- mittee}

Is a written answer in the House of Commons on November 12, the Minister of State for Commonwealth Relations, Mr. C. J. M. Alport, stated that in accordance with the recommendations of the Commonwealth Education Conference, representatives of all member countries in the Commonwealth met in London on October 27 under the chairmanship of Sir Henry Lintott. It was proposed to establish a Commonwealth Education Liaison Committee, comprising one representative of each member country and of Nigeria, and in addition the United Kingdom would appoint a member to represent the other Colonial territories. This Committee would follow up and record progress on the schemes of assistance agreed at the Oxford Conference and would also consider suggestions for the further improvement of Commonwealth co-operation in education, and, in particular, it would prepare material for submission to the next Commonwealth Education Conference, to be held in India in the winter of 1961-62, at the invitation of the Government of India. The chairman would be Sir Philip Morris, and under the general direction of the Liaison Committee there would be a Commonwealth Education Liaison Unit, consisting initially of a director (who would also be secretary to the Committee) and one administrative assistant. The Unit would supplement normal direct dealings between the countries of the Commonwealth on education, and would deal on request with inquiries from education authorities in Commonwealth countries and generally act as a reference centre. The cost of the Unit would be shared between member countries of the Commonwealth.

\section{United States and Great Britain to exchange Data on Advanced Gas-cooled Reactors}

Tete United States Atomic Energy Commission and the United Kingdom Atomic Energy Authority have signed a five-year agreement to exchange technical information on advanced gas-cooled reactors. The exchange, effective as from November 16, will be carried out under the terms of the agreement between the two countries for co-operation in the civil uses of atomic energy, which has been in effect since 1955. Data will be exchanged on development, design, construction and operation, as well as on related research and development, of the advanced gas-cooled reactors being built at Windscale, England, and on the U.S. experimental reactor project of this type at the Oak Ridge (Tennessee) National Laboratory. Information exchanged under this agreement will be made available to British and American industry.

\section{British Book Exhibition in Moscow}

A LARGE exhibition of British books and periodicals sponsored by the British Council and the Soviet Ministry of Culture is opening in Moscow on November 21 for a fortnight. A similar exhibition of Russian books and periodicals will be shown at the Festival Hall in London next February. This will be the largest exhibition of British books and periodicals to have been shown in the U.S.S.R. at any time, so far as is known. Between three and four thousand books will be exhibited together with six hundred. periodicals, a display of posters and large photographs. The exhibition will be shown in the main lecture hall of the Lenin Library, one of the largest libraries in the world. The books selected by the British Council have been provided free of charge by British publishers through the co-operation of the Publishers' Association. The main emphasis lies on science and technology, although there are important sections dealing with the arts and the humanities. Under the terms of the agreement made with the Soviet Ministry of Culture, there are no sections on religion, politics or economics. Two-thirds of the periodicals are on medical and scientific subjects. At the end of the exhibition all the British material will be handed over to the Soviet Ministry of Culture for use in Russian libraries and cultural institutions.

\section{New Zealand Research on Weed Transportation}

WEED species are sometimes inadvertently introduced into one country from another, but it is not always possible to establish the means by which this occurs. A. J. Healy, of the Botany Division, Department of Scientific and Industrial Research, Christ. church, has given some particular instances of introduction of foreign species into New Zealand (New Zealand Journal of Agricultural Research, 2, No. 2 ; April 1959). The first example is a straw envelope from a whisky bottle picked up in a rubbish 